\title{
Induction of Labor
}

National Cancer Institute

\section{Source}

National Cancer Institute. Induction of Labor. NCI Thesaurus. Code C92814.

The use of pharmacological and/or mechanical methods to initiate labor, including spontaneous rupture of membranes without contractions. Examples of methods include: artificial rupture of membranes, balloons, oxytocin, prostaglandin, laminaria, or other cervical ripening agents. (adapted from reVITALize) 